AMERICAN HOMICIDE 

RANDOLPH ROTH

\section{American Homicide}

THE BELKNAP PRESS OF HARVARD UNIVERSITY PRESS

Cambridge, Massachusetts

London, England

2009 
Copyright (c 2009 by the President and Fellows of Harvard College All rights reserved

Printed in the United States of America

\section{Library of Congress Cataloging-in-Publication Data}

Roth, Randolph, 1951-

American homicide / Randolph Roth.

p. $\mathrm{cm}$

Includes bibliographical references and index.

ISBN 978-0-674-03520-1 (cloth : alk. paper)

1. Homicide-United States-History. I. Title.

HV6524.R68 2009

364.1520973 -dc22 2009016830 


\section{To Allison,}

the memory of William Slothrop, and God's second sheep 
